\title{
$\mathrm{Ti}-\mathrm{Al}-\mathrm{Fe}$ 계 합금의 고온산화거동에 미치는 $\mathrm{Fe}$ 의 영향
}

\author{
윤장원 · 현용택*† · 김정한* - 염종택* · 윤석영 \\ 부산대학교 재료공학부, *재료연구소 특수합금연구그룹
}

\section{Effect of Fe on the High Temperature Oxidation of Ti-Al-Fe Alloys}

\author{
Jang-Won Yoon, Yong-Taek Hyun*†, Jeoung-Han Kim*, Jong-Taek Yeom* and Seog-Young Yoon
}

Department of Materials Science and Engineering, Pusan National University, Busan 609-735, Korea

*Special Alloys Research Group, Korea Institute of Materials Science (KIMS), Changwon 642-831, Korea

\author{
(2011년 5월 9일 접수 : 2011년 5월 30일 최종수정 : 2011년 5월 30일 채택)
}

\begin{abstract}
In this paper, high temperature oxidation behavior of newly developed alloys, Ti-6Al-4Fe and Ti-6Al-1Fe, is examined. To understand the effect of $\mathrm{Fe}$ on the air oxidation behavior of the Ti-Al-Fe alloy system, thermal oxidation tests are carried out at $700^{\circ} \mathrm{C}$ and $800^{\circ} \mathrm{C}$ for 96 hours. Ti-6Al-4V alloy is also prepared and tested under the same conditions for comparison with the developed alloys. The oxidation resistance of the Ti-Al-Fe alloy system is superior to that of Ti-6Al-4V alloy. Ti-6Al-4V shows the worst oxidation resistance for all test conditions. This is not a result of the addition of Fe, but rather it is due to the elimination of $\mathrm{V}$, which has deleterious effects on high temperature oxidation. The oxidation of the Ti-Al-Fe alloy system follows the parabolic rate law. At $700^{\circ} \mathrm{C}, \mathrm{Fe}$ addition does not have a noticeable influence on the amount of weight gain of all specimens. However, at $800^{\circ} \mathrm{C}$, Ti-6Al-4Fe alloy shows remarkable degradation compared to Ti-6Al-1Fe and Ti-6Al. It is discovered that the formation of $\mathrm{Al}_{2} \mathrm{O}_{3}$, a diffusion resistance layer, is remarkably hindered by a relative decrease of the $\alpha$ volume fraction. This is because Fe addition increases the volume fraction of $\beta$ phase within the Ti-6Al-xFe alloy system. Activities of $\mathrm{Al}, \mathrm{Ti}$, and $\mathrm{Fe}$ with respect to the formation of oxide layers are calculated and analyzed to explore the oxidation mechanism.
\end{abstract}

Key words Ti-Al-Fe alloy, oxidation, iron, alloying element, oxide layer.

\section{1. 서}

타이타늄 합금은 우수한 비강도, 내피로성 및 내부식 성 등으로 인하여 항공기용 부품 등의 구조재로 널리 사 용되고 있다. 그중에서도 Ti-6Al-4V 합금은 $\alpha+\beta$ 합금 으로 상용합금 중에서 가장 폭넓게 사용되고 있는 합금 으로 인장 및 피로특성이 우수하고, 비교적 고온인 약 $482^{\circ} \mathrm{C}$ 까지 금속학적인 안정성이 좋다. 그러나 $\beta$ 상 안정 화원소인 $\mathrm{V}$ 의 첨가는 가격상승의 원인이 되었으며, 이와 같은 이유로 기계적·화학적 성질을 저하시키지 않으면 서 $\mathrm{V}$ 을 대체하는 합금원소를 첨가한 합금개발이 이루어 지게 되었다. $\mathrm{Fe}$ 는 가격이 저렴하면서도 강력한 $\beta$ 상 안 정화 원소로서 $\mathrm{Mo}$ 당량이 $\mathrm{V}$ 의 약 3.8 배에 이르며, 실 제로 $\mathrm{Fe}$ 를 첨가하였을 경우 기본물성이 크게 향상되는 것 으로 보고되었다. ${ }^{1-4)}$ 이러한 타이타늄 합금은 항공기 또 는 발사체의 부품에 적용가능성이 높은데, 이와 같은 부

${ }^{\dagger}$ Corresponding author

E-Mail : ythyun@kims.re.kr (Y. -T. Hyun)
품은 우수한 내산화특성이 요구된다. 이런 요구에 맞추 어 최근에 $\mathrm{Ti}-6 \mathrm{Al}-4 \mathrm{~V}$ 합금의 $\mathrm{V}$ 대신에 $\mathrm{Fe}$ 를 첨가한 저 비용 Ti-Al-Fe계 합금이 개발되었다. ${ }^{3}$ 이 합금은 상용 Ti$6 \mathrm{Al}-4 \mathrm{~V}$ 합금에 비하여 우수한 기계적 강도를 갖는 것으 로 보고되고 있지만, $\mathrm{V}$ 을 대체한 $\mathrm{Fe}$ 가 Ti-Al-Fe계 합금 의 고온산화특성에 미치는 영향에 대한 연구는 미미한 실 정이다. Shida, ${ }^{5)} \mathrm{Lee}^{6}$ 및 $\mathrm{Kim}^{7)}$ 등은 $\mathrm{TiAl}$ 계 금속간화합 물에서 $\mathrm{Fe}$ 의 영향에 대한 연구를 진행한 바가 있는데 연 구자마다 상이한 결과를 보고하고 있다. Shida 등은 $\mathrm{Fe}$ 가 내산화성에 영향을 미치지 않는다고 보고한 반면 Lee 및 $\mathrm{Kim}$ 등은 $\mathrm{Fe}$ 가 내산화성을 향상 시킨다고 보고하였 다. 본 연구에서는 $\beta$ 안정화원소인 $\mathrm{Fe}$ 를 첨가한 Ti-Al-Fe 3 원계 $\alpha+\beta$ 합금의 고온산화거동과 $\mathrm{Fe}$ 의 영향에 대하여 조사하였다.

\section{2. 실험 방법}

\section{1 합금 및 시편의 제작}

본 연구에 사용된 Ti-6Al-4V, Ti-6Al, Ti-6Al-1Fe 및 Ti- 
$6 \mathrm{Al}-4 \mathrm{Fe}$ 합금은 유도스컬용해(Induction Skull Melting, ISM)법을 이용하여 직경이 $50 \mathrm{~mm}$, 길이가 $180 \mathrm{~mm}$ 인 봉 상의 합금을 제조하였다. 제조된 합금은 $40 \times 8 \times 4 \mathrm{~mm}^{3}$ 크기의 고온산화시편으로 가공하였다. 시편은 산화시에 표 면에 일정한 두께로 산화층이 생성되게 하기 위하여 $\mathrm{SiC}$ 연마지로 \#1,500까지 연마하고, 에탄올과 아세톤을 사용 하여 초음파 세척한 후 등온산화실험을 실시하였다.

\section{2 고온산화실험}

등온산화실험은 TGA (Thermogravimetric analyzer)를 이용하여 700 및 $800^{\circ} \mathrm{C}$ 의 대기 분위기에서 실시하였으 며, 이때의 무게변화는 70초 간격으로 자동 측정하였다. 실험온도까지 승온시 시편의 산화방지를 위하여 연속적으 로 고순도의 $\mathrm{Ar}$ 가스를 주입하였으며, 실험온도에 도달하 면 질소와 산소의 비율이 79:21로 혼합된 공기를 $16 \mathrm{ml} /$ $\min$ 의 속도로 시편이 장입된 챔버내로 흘려주었다. 각 합 금의 온도별 상분율의 계산은 JMatPro 6.01 code를 사용 하였으며, 산화실험 후 생성된 산화물은 $\mathrm{X}$ 선 분석법 $(\mathrm{X}-$ ray Diffraction, XRD) 및 EPMA (Electron Probe Microanalyzer), 주사전자현미경(Scanning Electron Microscope, $\mathrm{SEM})$ 등을 사용하여 조사하였다.

\section{3. 결 과}

\section{1 중량변화}

Ti-Al-Fe계 합금 및 상용의 Ti-6Al-4V 합금에 대하여 대기분위기 $700^{\circ} \mathrm{C}$ 에서 96 시간 동안 산화실험수행 결과를 Fig. 1에 나타내었다. 시간에 따른 단위면적당 무게변화 로 산화정도를 나타내었는데, 그림에서 알 수 있듯이 실 험온도에서의 내산화성은 Ti-6Al, Ti-6Al-4Fe, Ti-6Al-1Fe, Ti-6Al-4V 순으로 우수함을 알 수 있다. 이들 합금의 등

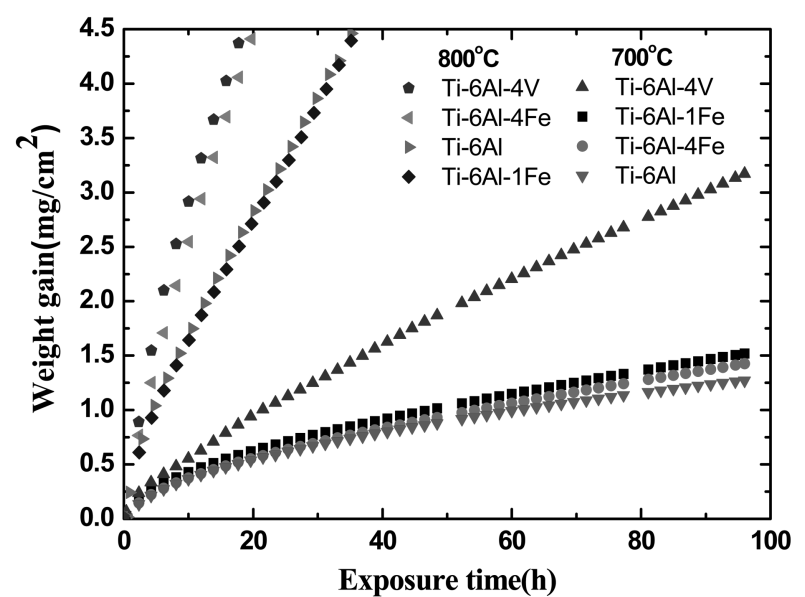

Fig. 1. Isothermal oxidation curves of Ti-6Al-xM alloys in air at 700 and $800^{\circ} \mathrm{C}$.
온산화곡선들은 공통적으로 초기에 포물선적 거동을 보 인다. 즉, 시험초기에 시편의 표면은 고온의 대기 중에 직접 노출되어 급속히 산화가 진행되지만 시간의 경과에 따라 형성된 산화막이 각종 이온의 확산경로를 방해해 산 화를 방지하기 때문에 산화속도는 점차적으로 감소된다. 이는 고온산화거동이 대기로부터 산소이온의 내부확산 또 는 모재 금속이온의 외부확산에 의해 율속되고 있음을 의 미한다. 50 시간 이후부터는 선형적 산화거동을 보이는데 이는 확산경로를 막는 장벽역할을 하던 산화피막의 보호 능력보다 확산속도의 증가가 산화에 더 크게 영향을 미 치기 때문이다. 실험 후 시편을 육안으로 관찰한 결과 Ti$6 \mathrm{Al}-4 \mathrm{~V}$ 시편에서 산화층의 국부적인 박리 및 균열발생을 확인할 수 있었다. 이는 $700^{\circ} \mathrm{C}$ 의 고온에서 생성된 모재 에 불안정하게 붙어있던 두꺼운 산화층이 실험 후 냉각 되면서 열충격에 의해서 박리된 것으로 판단된다. 이와 같 은 산화층의 박리현상은 Ti-6Al-4V 합금에서만 관찰되었 으며, Ti-Al-Fe계 합금에서는 이러한 현상이 발생하지 않 았다. 한편 $\mathrm{Fe}$ 함량에 따른 내산화성의 차이는 Ti-6Al$1 \mathrm{Fe}$ 합금보다 Ti-6Al-4Fe 합금의 내산화성이 우수한 것 으로 나타났으나 그 차이는 크지 않았다. $800^{\circ} \mathrm{C}$ 에서의 고 온산화실험에서는 모든 합금의 내산화성이 급격히 감소 하였으며, 모두 산화층의 박리가 발생하였다. Ti-6Al 합 금과 Ti-6Al-1Fe 두 합금 사이에는 유사한 산화거동이 관 찰되었으나, Ti-6Al-4Fe 합금은 이들보다 빠른 산화속도 를 나타내었다.

\section{2 산화층 및 합금원소의 거동}

Fig. 2는 산화실험 후 시편의 횡단면을 EPMA를 이용 하여 합금원소들의 분포를 분석한 결과이다. $\alpha$ 상 안정화 원소로 알려진 $\mathrm{Al}$ 은 $\alpha$ 상에, $\beta$ 상 안정화원소인 $\mathrm{V}$ 과 $\mathrm{Fe}$ 는 $\beta$ 상에 주로 고용되어 있는 것을 알 수 있다. 산화층에 함 유된 $\mathrm{Ti}$ 와 $\mathrm{Al}$ 의 농도는 모재부보다 떨어지는 반면 산소 의 농도는 산화층에서 높게 나타난다. 이는 H. Guleryuz 등의의 연구결과와 같이 합금원소의 외부확산과 산소의 내 부확산으로 인해 산화층이 $\mathrm{TiO}_{2}$ 와 $\mathrm{Al}_{2} \mathrm{O}_{3}$ 로 이루어지기 때 문이다. 이 산화층은 연구자에 따라 $\mathrm{TiO}_{2}$ 와 $\mathrm{Al}_{2} \mathrm{O}_{3}$ 가 반 복된 산화층으로 보고되기도 한다. ${ }^{9)}$ 이는 $\mathrm{Al}$ 이 함유된 타 이타늄 합금에서 관찰되는 $\mathrm{TiO}_{2}$ 와 $\mathrm{Al}_{2} \mathrm{O}_{3}$ 로 이루어진 산 화층이 형성되는 기구와 같다. 산화층이 성장하면서 모 재와 산화층 사이에 균열이 발생하면 균열사이에 산소분 압이 증가하여 $\mathrm{TiO}_{2}$ 와 $\mathrm{Al}_{2} \mathrm{O}_{3}$ 로 이루어진 새로운 산화층 이 형성된다. 따라서 단층의 산화막을 형성한 본 시험편 도 온도 및 시간의 증가 시 산화층의 박리가 일어나지 않는다면 $\mathrm{TiO}_{2}$ 와 $\mathrm{Al}_{2} \mathrm{O}_{3}$ 가 반복되는 산화층이 형성될 것 으로 사료된다. 산화층과 모재사이의 계면에서는 산소와 질소의 농도가 증가된 것을 확인할 수 있다. TiAl계 금 
(a)
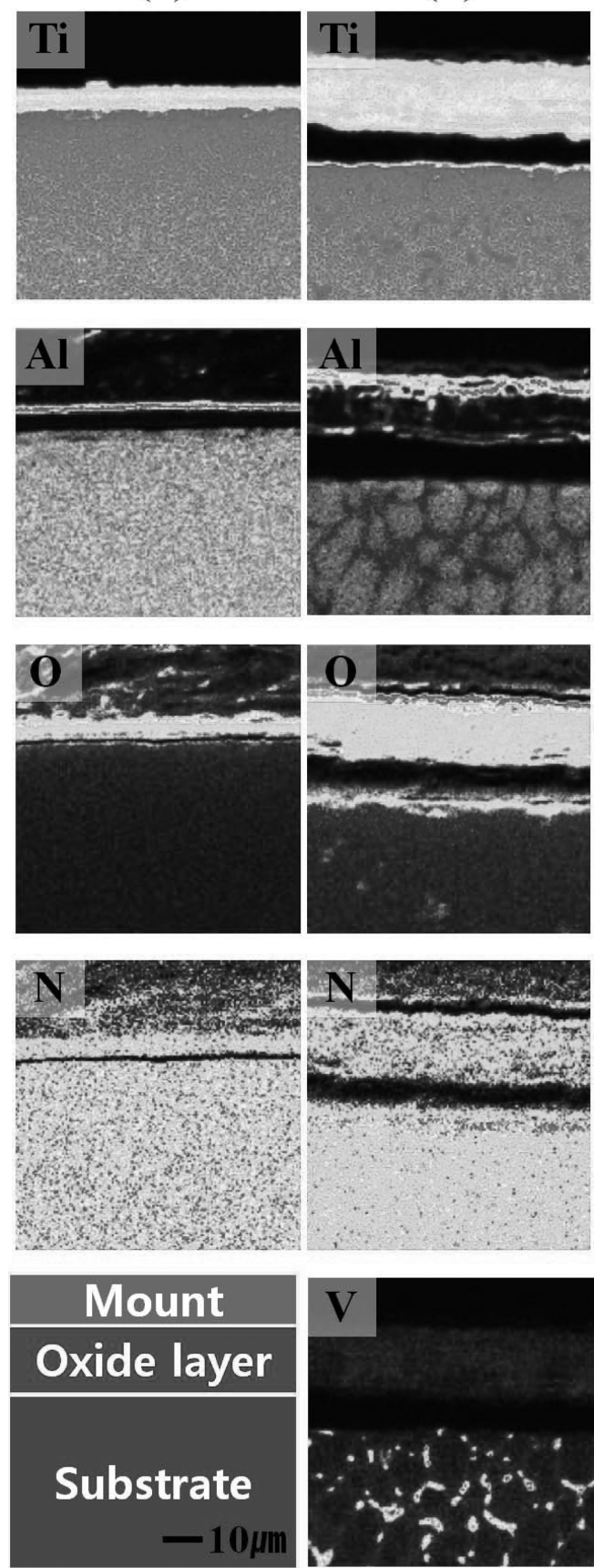

(b)
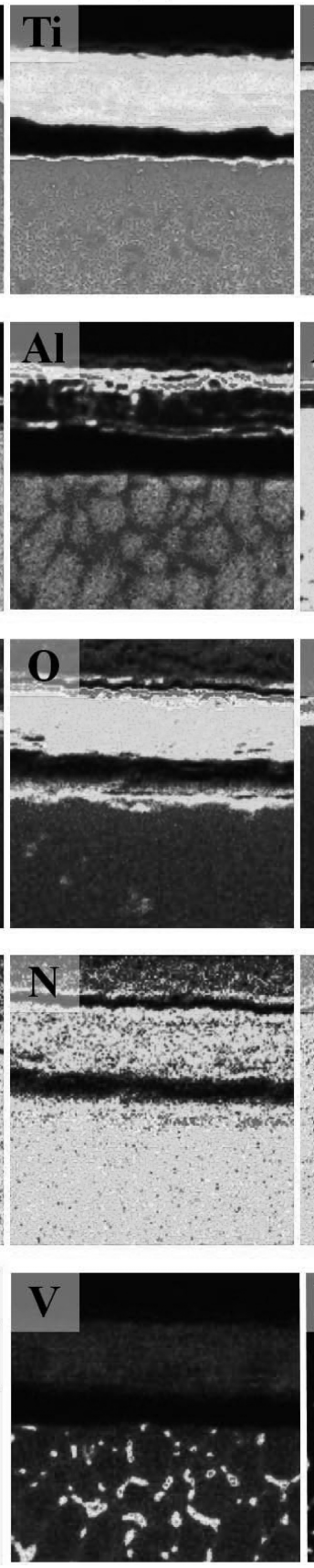
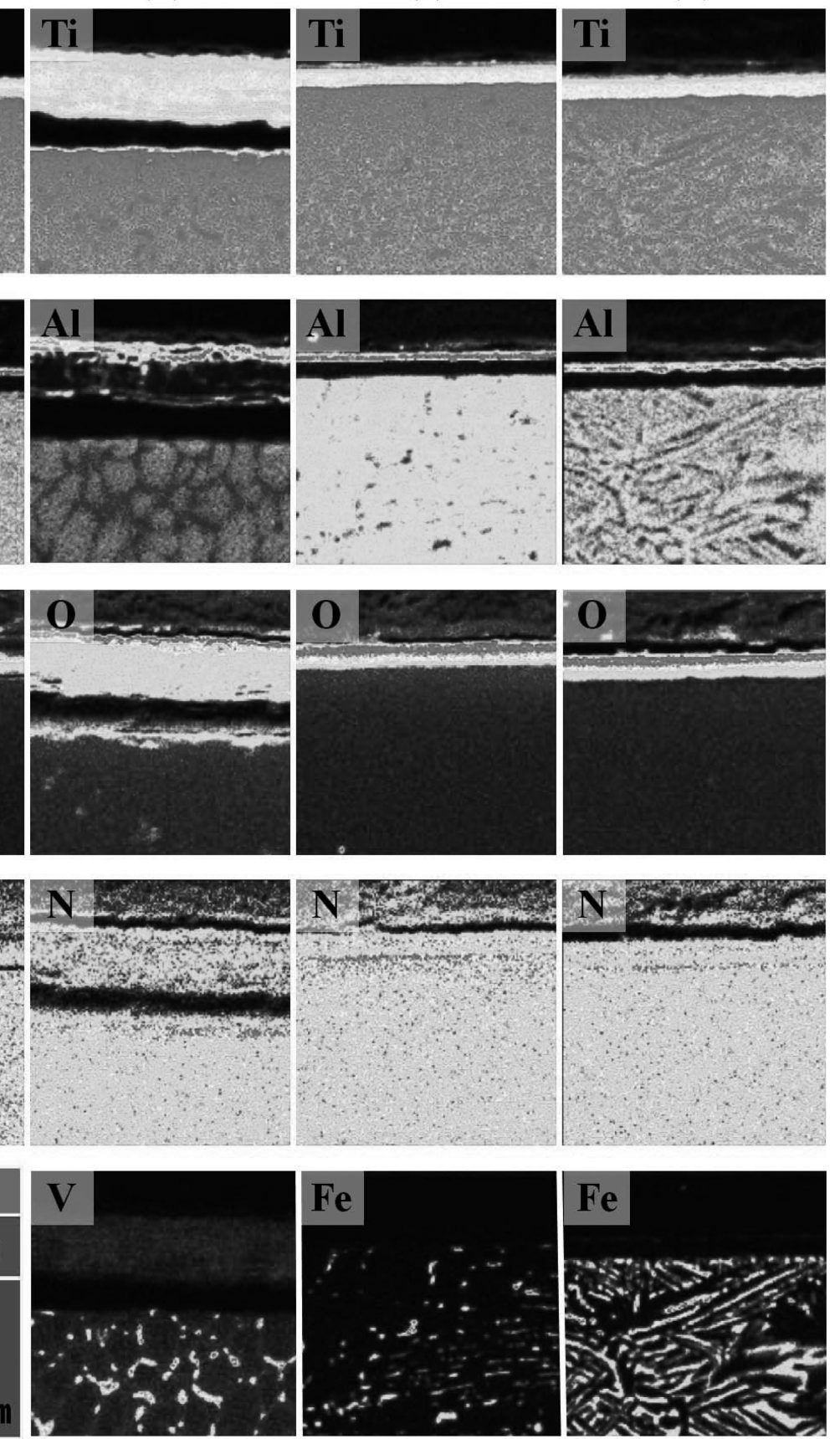

Fig. 2. EPMA mapping of cross sectional images after isothermal oxidation at $700^{\circ} \mathrm{C}$ for $96 \mathrm{~h}$ in air (a) Ti-6Al, (b) Ti-6Al-4V, (c) Ti-6Al$1 \mathrm{Fe}$ and $(\mathrm{d}) \mathrm{Ti}-6 \mathrm{Al}-4 \mathrm{Fe}$.

속간화합물에서는 내부로의 질소 확산에 의한 모재계면 에 생성되는 질화물은 취약한 층을 형성하여 산화층의 박 리 및 연속적인 $\mathrm{Al}_{2} \mathrm{O}_{3}$ 보호피막의 형성을 방해한다고 알 려져 있다. ${ }^{10)}$ 그러나 본 연구에서는 Fig. 2에 나타난 것 과 같이 Ti-6Al-1Fe 합금이 Ti-6Al-4Fe 합금보다 모재계 면의 질소농도가 높음에도 불구하고 연속적인 $\mathrm{Al}_{2} \mathrm{O}_{3}$ 층이 형성되었다. 각종 이온의 확산에 중요한 장벽 역할을 하 는 $\mathrm{Al}_{2} \mathrm{O}_{3}$ 층은 Ti-6Al-4V 합금에서 분절되고 굴곡져 있는
형태를 나타낸 반면, Ti-6Al, Ti-6Al-1Fe, Ti-6Al-4Fe 합 금에서는 치밀한 산화층이 형성된 것을 알 수 있다. 이 는 Ti-6Al-4V 합금에서 $\mathrm{V}$ 이 $\mathrm{TiO}_{2}$ 내의 기공을 증가시킴 으로써 $\mathrm{TiO}_{2}$ 의 성장을 촉진시켜 $\mathrm{Al}_{2} \mathrm{O}_{3}$ 층 생성에 악영향 을 미치기 때문인 것으로 알려져 있다. ${ }^{11)}$

고온산화실험 후 산화층 표면 및 단면조직을 $\mathrm{SEM}$ 으로 관찰한 결과를 Fig. 3과 4에 나타내었다. Fig. 3에서 보 는바와 같이 Ti-6Al 합금의 산화층 표면은 비교적 미세 

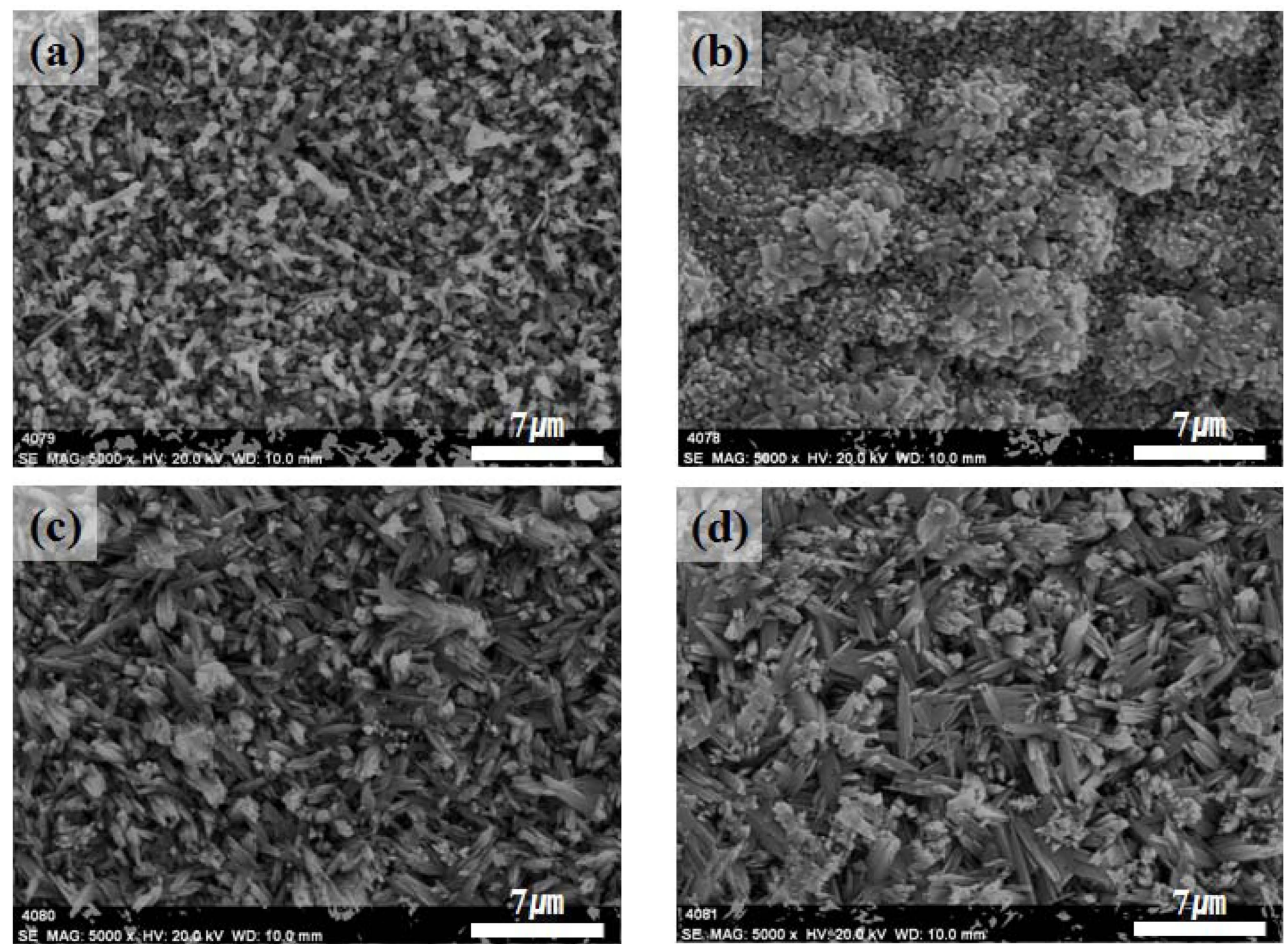

Fig. 3. SEM photographs of the top surface of (a) Ti-6Al, (b) Ti-6Al-4V, (c) Ti-6Al-1Fe and (d) Ti-6Al-4Fe after isothermal oxidation test at $700^{\circ} \mathrm{C}$ for $96 \mathrm{~h}$ in air.

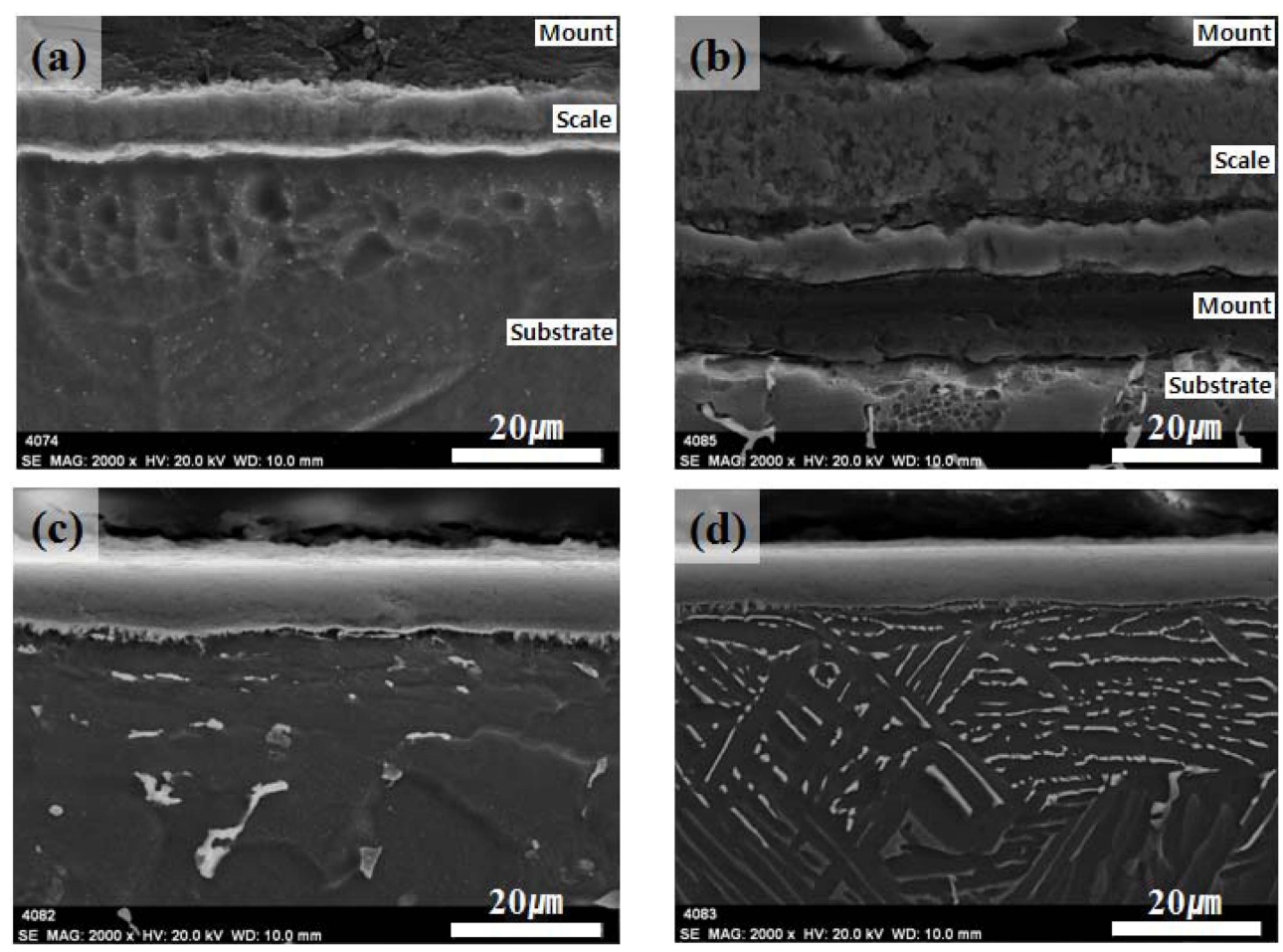

Fig. 4. SEM cross sectional images of (a) Ti-6Al, (b) Ti-6Al-4V, (c) Ti-6Al-1Fe and (d) Ti-6Al-4Fe after isothermal oxidation test at $700^{\circ} \mathrm{C}$ for $96 \mathrm{~h}$ in air.

한 $\mathrm{TiO}_{2}$ 입자가 균일하게 분산된 형태를 갖는 것을 알 수 있고, Ti-6Al-4V 합금은 $\mathrm{TiO}_{2}$ 가 국부적으로 응집되면서 표 면거칠기가 심한 산화층이 형성되는 것을 관찰할 수 있
다. 반면 $\mathrm{Fe}$ 가 첨가된 Ti-6Al-1Fe 및 Ti-6Al-4Fe 합금은 침상 형태의 $\mathrm{TiO}_{2}$ 로 이루어진 산화층이 관찰되었다. 각 합금에 형성된 산화층의 두께는 Fig. 4 에 나타난 것과 같 


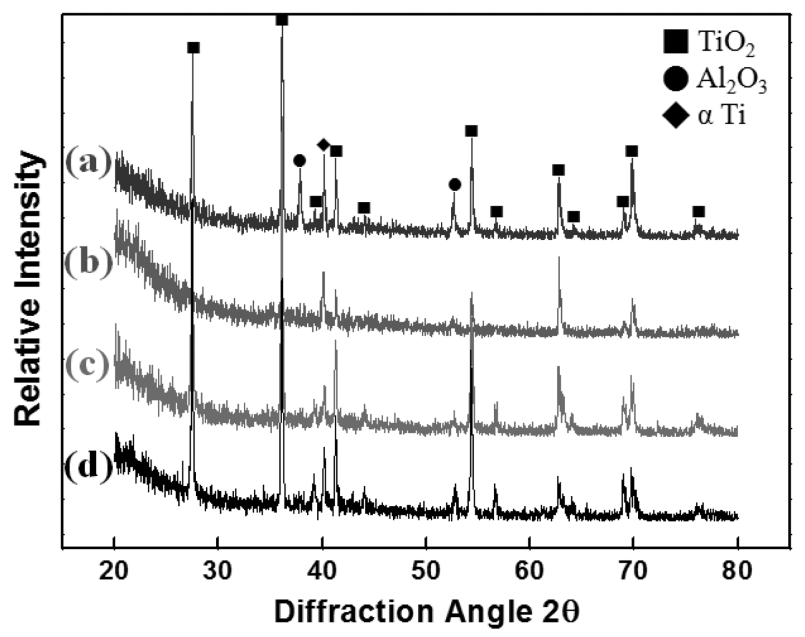

Fig. 5. X-ray diffraction patterns of the oxide scales (a) Ti-6Al, (b) Ti-6Al-4V, (c) Ti-6Al-1Fe and (d)Ti-6Al-4Fe.

이 Ti-6Al-4V 합금이 약 $16 \mu \mathrm{m}$ 로 가장 두꺼운 것으로 나타났고, Ti-6Al, Ti-6Al-1Fe, Ti-6Al-4Fe 합금은 약 8 $10 \mu \mathrm{m}$ 로 거의 일정하였다. 무게증가량이 클수록 산화층의 두께는 증가하는 경향을 보이나 Ti-6Al 합금의 내산화성 이 가장 우수함에도 불구하고 Ti-6Al-4Fe 합금보다 산화 층이 더 두껍게 형성되었다. Taylor ${ }^{12)}$ 는 $\mathrm{Fe}$ 산화물이 $\mathrm{TiO}_{2}$ 내에 고용된다고 보고하였는데, 본 연구에서 수행한 Ti$6 \mathrm{Al}-4 \mathrm{Fe}$ 합금에서도 $\mathrm{Fe}$ 가 산화층에 고용되어 Fig. 4(d)와 같이 산화피막이 치밀한 반면 Ti-6Al은 Fig. 4(a)와 같이 치밀하지 못하기 때문에 산화층의 두께에 차이가 생긴 것 으로 사료된다.

Fig. 5는 고온산화실험 후 시편의 내외부에 형성된 산 화물의 상분석을 위해서 $\mathrm{XRD}$ 를 이용하여 측정한 결과 이다. 모든 합금의 시편에서 타이타늄 합금의 고온산화 에서 일반적으로 관찰되는 $\mathrm{TiO}_{2}$ 가 주를 이루며, $\mathrm{Al}_{2} \mathrm{O}_{3}$ 또 한 형성되었다. $\mathrm{Ti}$ 와 $\mathrm{Al}$ 은 서로 비슷한 활동도를 가져 산 화 초기에는 산화물이 경쟁적으로 생성되지만, 시간이 경 과함에 따라 많은 내부결함으로 인해 성장이 빠른 $\mathrm{TiO}_{2}$ 가 산화층의 주를 이루기 때문이다. 이는 Fig. 2의 EPMA 결과와도 잘 일치한다.

\section{4. 고 찰}

\subsection{Ti-6Al-xFe 합금의 내산화성에 미치는 $\mathrm{Fe}$ 의 영향}

Fig. 1에서 내산화성은 Ti-6Al이 가장 우수하고 Ti-6Al$4 \mathrm{Fe}, \mathrm{Ti}-6 \mathrm{Al}-1 \mathrm{Fe}, \mathrm{Ti}-6 \mathrm{Al}-4 \mathrm{~V}$ 순으로 우수한 것으로 나타 났다. 대기분위기의 모든 실험온도구간에서 Ti-6Al-4V 합 금보다 Ti-Al-Fe계 합금이 훨씬 우수한 산화저항성을 보 였다. 이는 $\mathrm{Fe}$ 의 첨가로 내산화성이 증진 되었다기보다는 기존의 연구결과에서 알려진 바와 같이 내산화성에 유해
한 원소로 알려진 $\mathrm{V}$ 이 ${ }^{5)} \mathrm{Fe}$ 로 대체됨으로써 내산화성이 상대적으로 증진된 것으로 보인다. 이는 $\mathrm{Fe}$ 가 첨가된 $\mathrm{Ti}-$ $6 \mathrm{Al}-\mathrm{xFe}$ 계 합금이 $\mathrm{Ti}-6 \mathrm{Al}$ 보다 내산화성이 떨어지는 결 과에서도 확인할 수 있다. 한편 Fig. 2의 Ti-6Al-4Fe 합 금에서 $\mathrm{Al}_{2} \mathrm{O}_{3}$ 층은 $\mathrm{Ti}-6 \mathrm{Al}-1 \mathrm{Fe}$ 합금과 비교하여 상대적으 로 연속적인 층을 형성하지 못하고 단절된 양상을 보인 다. 이는 Ti-6Al-4Fe 합금의 $\beta$ 상 분율이 Ti-6Al-1Fe 합금 보다 높아 상대적으로 적은 양의 $\mathrm{Al}$ 이 고용되기 때문에 모재계면의 $\beta$ 상 부근은 $\mathrm{Al}_{2} \mathrm{O}_{3}$ 층 성장이 불균일하게 일어 나 연속적인 $\mathrm{Al}_{2} \mathrm{O}_{3}$ 층 대신 분절된 형태의 $\mathrm{Al}_{2} \mathrm{O}_{3}$ 층이 형 성된 것으로 판단된다. 일반적으로 $\beta$ 상의 분율이 높을수 록 내산화성이 $\alpha$ 상에 비해 떨어지는 것으로 알려져 있 다. ${ }^{13)}$ 본 연구에서는 $\beta$ 상 분율에 의한 내산화성 저하는 $700^{\circ} \mathrm{C}$ 에서는 거의 관찰되지 않았으나, $800^{\circ} \mathrm{C}$ 에서는 Ti-6Al$4 \mathrm{Fe}$ 합금의 내산화성이 상대적으로 감소되는 것으로 나타 났다. $800^{\circ} \mathrm{C}$ 에서의 상분율을 상용해석 프로그램 JMatPro 를 이용하여 측정한 결과 Fig. 6에 나타낸 것과 같이 Ti$6 \mathrm{Al}-1 \mathrm{Fe}$ 의 경우 $\beta$ 상이 $14 \%, \mathrm{Ti}-6 \mathrm{Al}-4 \mathrm{Fe}$ 의 경우 $45 \%$ 로 현 저한 차이를 보인다. 따라서 $\beta$ 상 분율이 높은 Ti-6Al-4Fe 합금이 Ti-6Al-1Fe 합금에 비하여 내산화성이 떨어지는 것 으로 판단된다.

대부분의 산화물은 이상적인 상태가 아니며 그들의 조 성은 화학양론적비에 따라 $\mathrm{n}$ 형 또는 $\mathrm{p}$ 형으로 나뉜다. 이 중 $\mathrm{Ti}$ 계 합금에서 주로 형성되는 $\mathrm{TiO}_{2}$ 와 $\mathrm{Al}_{2} \mathrm{O}_{3}$ 등은 $\mathrm{n}$ 형

(a)

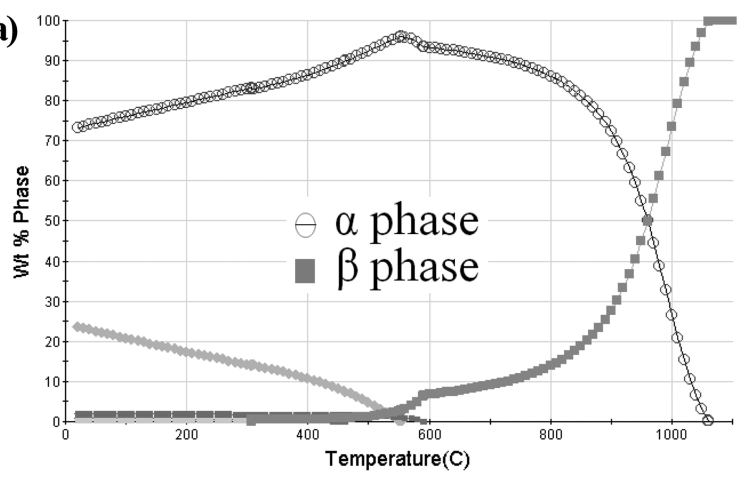

(b)

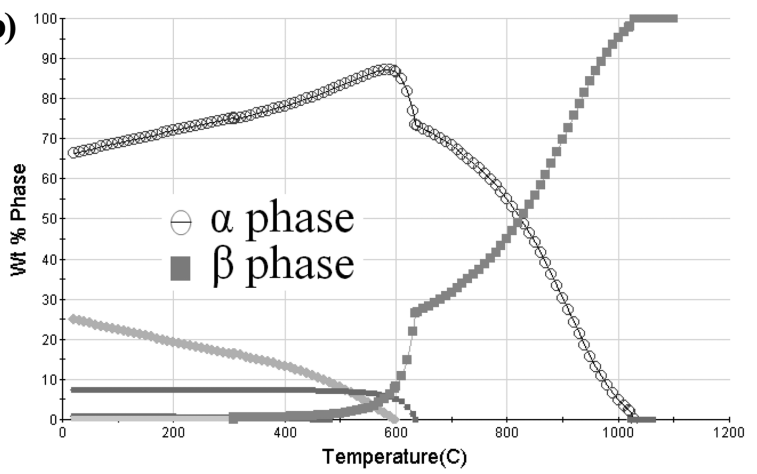

Fig. 6. Volume fraction of (a) Ti-6Al-1Fe and (b) Ti-6Al-4Fe from JMatPro 6.01 code. 
산화물이고 $\mathrm{FeO}$ 등은 $\mathrm{p}$ 형 산화물이다. 고온산화속도가 확 산에 의해 지배된다고 가정할 때 모재의 원자가(valence) 와 다른 원자가를 가지는 합금원소의 첨가는 산화속도의 변화를 일으킨다. $\mathrm{n}$ 형 산화물의 경우 모재보다 높은 원자 가를 가지는 합금원소는 산화속도의 저하를 일으키고 반 대의 경우에는 결함의 이동도를 높여 내산화성을 악화시 키게 된다. 본 연구에서 Ti-6Al, Ti-6Al-1Fe, Ti-6Al-4Fe 의 $700^{\circ} \mathrm{C}$ 산화시험 결과를 살펴보면 $\mathrm{Fe}$ 의 첨가가 산화 속도를 소폭 증가시키는 것으로 나타났다. 이는 $\mathrm{Fe}^{2+}$ 이온 이 첨가되면 전기적 중성을 유지하기 위해서 전자의 농 도가 감소하게 되고 질량 작용의 법칙에 의해서 침입형 $\mathrm{Ti}^{4+}$ 이온의 농도가 증가하기 때문이다. ${ }^{14)}$ 이렇게 침입형 $\mathrm{Ti}^{4+}$ 이온의의 농도가 증가하게 되면 외부 산화층으로의 확 산이 쉬워지게 된다. 실제로 $800^{\circ} \mathrm{C}$ 에서 Ti-6Al-4Fe는 Ti$6 \mathrm{Al}$ 과 비교해 크게 저하된 내산화성을 보였다. 이러한 결 과는 $\mathrm{TiAl}$ 계에서 $\mathrm{Fe}$ 첨가가 내산화성을 증진 시킨다는 보 고와 상충되는 것이다. Shida 등은 $\mathrm{Fe}$ 의 첨가가 $\mathrm{TiAl}$ 계 합금에서 거의 중성적인 역할을 하지만, 약 $2 \mathrm{wt} . \%$ 의 $\mathrm{Fe}$ 첨가는 소폭 내산화성을 증진 시키는 것으로 보고하였 다. Lee 등은 $\mathrm{TiAl}$ 계 합금에서 $\mathrm{Fe}$ 를 첨가한 경우 $800^{\circ} \mathrm{C}$ 에서 현저한 내산화성 증가를 보고하였다. 이는 Ti-Al-Fe 합금계에서 $\mathrm{Fe}$ 가 고온산화특성에 미치는 효과가 TiAl 합 금계와는 확연히 다름을 보여주고 있다. TiAl계 합금에 서는 $\mathrm{Al}_{2} \mathrm{O}_{3}$ 산화층이 여러층으로 비교적 활발히 생성 되 는데 이 $\mathrm{Al}_{2} \mathrm{O}_{3}$ 층은 안정구조로서 성장속도가 느려 전 체적인 산화물의 생성속도를 늦추는 역할을 한다. $\mathrm{Fe}$ 의 첨가는 +3 가의 $\mathrm{Al}$ 을 치환하면서 $\mathrm{Al}$ 의 이온농도를 증가 시킨다. 이는 $\mathrm{Al}_{2} \mathrm{O}_{3}$ 층을 성장시켜 $\mathrm{TiAl}$ 계 합금의 내산화 성을 향상시키는 것으로 보고되고 있다. 반면 Ti-6Al계에 서는 $\mathrm{TiAl}$ 계 보다 $\mathrm{Al}$ 함유량이 적어 상대적으로 $\mathrm{Al}_{2} \mathrm{O}_{3}$ 층의 효과는 크지 않아 $\mathrm{Fe}$ 의 첨가에 따른 내산화 효과 를 기대할 수 없게 된다.

\section{$4.2 \mathrm{Ti}, \mathrm{Al}, \mathrm{Fe}$ 원소의 활동도 영향}

모든 시험 합금들의 고온산화실험의 결과를 보면 공통 적으로 $\mathrm{Al}_{2} \mathrm{O}_{3}$ 와 $\mathrm{TiO}_{2}$ 가 교대로 형성되지만 시간 및 온 도가 충분치 못할 경우 $\mathrm{Al}_{2} \mathrm{O}_{3}$ 와 $\mathrm{TiO}_{2}$ 로 이루어진 단 층의 산화막이 형성되어 있는 것을 확인 할 수 있었다. 이는 다음과 같은 두 가지 반응이 교대로 나타났음을 의 미한다.

$$
\begin{aligned}
& 2 \mathrm{Al}(\mathrm{l})+3 / 2 \mathrm{O}_{2}(g)=\mathrm{Al}_{2} \mathrm{O}_{3}(s) \\
& \mathrm{Ti}(\mathrm{s})+\mathrm{O}_{2}(g)=\mathrm{TiO}_{2}(s)
\end{aligned}
$$

한편 $\mathrm{Fe}$ 산화물의 경우 다음과 같은 3 가지 반응을 예 측할 수 있다.

$$
\begin{aligned}
& \mathrm{Fe}(s)+1 / 2 \mathrm{O}_{2}(g)=\mathrm{FeO}(s) \\
& 2 \mathrm{Fe}(s)+\frac{3}{2} \mathrm{O}_{2}(g)=\mathrm{Fe}_{2} \mathrm{O}_{3}(s) \\
& 3 \mathrm{Fe}(s)+2 \mathrm{O}_{2}(g)=\mathrm{Fe}_{3} \mathrm{O}_{4}(s)(5)
\end{aligned}
$$

위 5 가지 반응에 대해 온도에 따른 Gibbs 자유에너지 는 다음과 같이 표현될 수 있다. ${ }^{15)}$

$$
\begin{aligned}
& \Delta G_{1, T}^{O}=-1,676,000+320 T \\
& \Delta G_{2, T}^{O}=-910,000+173 T \\
& \Delta G_{3, T}^{O}=-263,000+64 T \\
& \Delta G_{4, T}^{O}=-810,520+254 T \\
& \Delta G_{5, T}^{O}=-1,102,200+307 T \\
& \text { 또는 } \\
& \Delta G_{1, T}^{O}=-R T \ln K_{1}=-R T \ln \frac{a_{\mathrm{Al}_{2} \mathrm{O}_{3}}}{\left(a_{\mathrm{Al}}\right)^{2} \cdot\left(p_{\mathrm{O}_{2}}\right)^{3 / 2}} \\
& \Delta G_{2, T}^{O}=-R T \ln K_{2}=-R T \ln \frac{a_{T i O_{2}}}{a_{T i} \cdot\left(p_{\mathrm{O}_{2}}\right)^{2}} \\
& \Delta G_{3, T}^{O}=-R T \ln K_{3}=-R T \ln \frac{a_{F e O}}{a_{F e} \cdot\left(p_{\mathrm{O}_{2}}\right)^{1 / 2}} \\
& \Delta G_{4, T}^{O}=-R T \ln K_{4}=-R T \ln \frac{a_{\mathrm{Fe}_{2} \mathrm{O}_{3}}}{\left(a_{\mathrm{Fe}}\right)^{2} \cdot\left(p_{\mathrm{O}_{2}}\right)^{3 / 2}} \\
& \Delta G_{5, T}^{O}=-R T \ln K_{5}=-R T \ln \frac{a_{\mathrm{Fe}_{3} \mathrm{O}_{4}}}{\left(a_{\mathrm{Fe}}\right)^{3} \cdot\left(p_{\mathrm{O}_{2}}\right)^{2}}
\end{aligned}
$$

$\mathrm{Du}$ 등은 $\mathrm{Al}_{2} \mathrm{O}_{3}$ 와 $\mathrm{TiO}_{2}$ 의 활동도를 최대값인 1 로 놓고 $\mathrm{Al}, \mathrm{Ti}$ 의 최소 활동도 값을 구하였다. ${ }^{9)}$ 유사한 방법으로 $\mathrm{Fe}$ 의 최소 활동도 값을 구하면 Table 1과 같다. 여기서 $\alpha_{\min \mathrm{Al}}$ 은 $\alpha_{\min \mathrm{Ti}}$ 보다 3 order 만큼 더 큰 값이 요구되는 것을 알 수 있는데 이는 초기 산화시 $\mathrm{TiO}_{2}$ 층이 먼저 생 성될 수 있음을 의미한다. 또한 $\mathrm{FeO}, \mathrm{Fe}_{2} \mathrm{O}_{3}$ 및 $\mathrm{Fe}_{3} \mathrm{O}_{4}$ 의 경우 $\mathrm{Al}_{2} \mathrm{O}_{3}, \mathrm{TiO}_{2}$ 보다 훨씬 높은 수준의 활동도를 요구하 고 있음을 알 수 있다. 따라서 실제로 $\mathrm{Fe}$ 의 산화물이 생 성되기는 어려울 것으로 판단되고 실제로 $\mathrm{EPMA}$ 와 $\mathrm{XRD}$ 결과에서 동일하게 확인되었다. 실제 Ti-6Al-xFe 계에서 각

Table 1. The calculated minimum values of $\alpha_{\mathrm{Al}}$ and $\alpha_{\mathrm{Ti}}$ for the formation of $\mathrm{Al}_{2} \mathrm{O}_{3}$ and $\mathrm{TiO}_{2}$ at $P_{O_{2}}=0.21$ atm at between 700 and $800^{\circ} \mathrm{C}$.

\begin{tabular}{ccc}
\hline & 700 & 800 \\
\hline$\alpha_{\operatorname{min~Al}}$ & $7.6 \times 10^{-37}$ & $1.2 \times 10^{-32}$ \\
$\alpha_{\operatorname{min~Ti}}$ & $7.3 \times 10^{-40}$ & $2.6 \times 10^{-35}$ \\
$\alpha_{\operatorname{min~Fe}}($ for $\mathrm{FeO})$ & $3.5 \times 10^{-11}$ & $7.3 \times 10^{-10}$ \\
$\alpha_{\operatorname{min~Fe}}\left(\right.$ for $\left.\mathrm{Fe}_{2} \mathrm{O}_{3}\right)$ & $4.3 \times 10^{-16}$ & $8.0 \times 10^{-14}$ \\
$\alpha_{\operatorname{min~Fe}}\left(\right.$ for $\left.\mathrm{Fe}_{3} \mathrm{O}_{4}\right)$ & $4.2 \times 10^{-15}$ & $2.9 \times 10^{-13}$ \\
\hline
\end{tabular}


원소의 활동도가 얼마인지는 알려져 있지 않으나 Ti-12.6Al 합금의 $800^{\circ} \mathrm{C}$ 에서 $\alpha_{\mathrm{Al}}$ 이 $2.8 \times 10^{-4}, \alpha_{\mathrm{Ti}}$ 가 0.81 로 보고되 어 있어 ${ }^{16)} \mathrm{TiO}_{2}$ 산화물이 다른 산화물 보다 먼저 생성될 것임을 반증하고 있다. Ti-6Al-xFe 계에서 $\mathrm{Fe}$ 의 활동도는 보고되고 있지 않으나 Table 1의 결과에서 다른 합금원 소에 비해 크게 낮을 것으로 예상된다.

\section{5. 결 론}

Ti-6Al, Ti-6Al-1Fe, Ti-6Al-4Fe 및 상용의 Ti-6Al-4V 합금을 고온에서 등온산화시킨 결과 다음과 같은 결론을 얻었다.

1) $700^{\circ} \mathrm{C}$ 에서의 내산화성은 Ti-6Al, Ti-6Al-4Fe, Ti-6Al$1 \mathrm{Fe}, \mathrm{Ti}-6 \mathrm{Al}-4 \mathrm{~V}$ 합금 순으로 우수하나, Ti-6Al-4V 합금을 제외한 합금들의 내산화성 차이는 크지 않았다. 그러나 $800^{\circ} \mathrm{C}$ 에서는 Ti-6Al-4Fe의 내산화성이 Ti-6Al- $1 \mathrm{Fe}$ 에 비 해 크게 악화된 경향을 보였다.

2) Ti-6Al-4V 합금에 비해 Ti-6Al-xFe 합금들의 내산화 성이 우수한 이유는 $\mathrm{Fe}$ 의 효과보다는 내산화성 유해 원 소인 $\mathrm{V}$ 이 제거됨으로써 발생한 결과였다.

3) Ti-6Al-xFe계 합금에서 Fe원소는 기존의 TiAl계에서 와는 달리 $\beta$ 상의 분율 증가로 인한 $\mathrm{Al}$ 이 고용된 $\alpha$ 상의 감소로 주 확산저항층인 $\mathrm{Al}_{2} \mathrm{O}_{3}$ 형성을 방해하는 역할을 하 였다.

\section{참 고 문 헌}

1. U. Zwicker, K. Buhler, R. Muller, H. Beck, H. J. Schmid and J. Frest, in Proceedings of 4th International Conference on Titanium; Titanium ' 80 Science and Technology (Kyoto, Japan, May 1980) ed. by H. Kimura and O. Izumi
(Metallurgical Society of AIME, Warrendale, PA, USA, 1980) p. 505.

2. P. J. Bania, A. J. Hutt, R. E. Adams and W. M. Parris, in Proceedings of 7th International Conference on Titanium; Titanium '92 Science and Technology (San Diego, USA, June 1992) ed. by F. H. Froes and I. L. Caplan (Minerals, Metals and Materials Society, Warrendale, PA, USA, 1993) p. 2787.

3. H. W. Jeong, S. E. Kim, Y. T. Hyun and Y. T. Lee, J. Kor. Inst. Met. \& Mater., 39(1), 34 (2001) (in Korean).

4. H. Fujii and K. Takahashi, Nippon Steel Tech. Rep., 85(1), 113 (2002).

5. Y. Shida and H. Anada, Oxidation of Metals, 45(1-2), 197 (1996).

6. D. B. Lee, Metals and Materials Int., 11(4), 313 (2005).

7. M. H. Kim and D. B. Lee, J. Kor. Inst. Surf. Eng., 33(4), 281 (2000) (in Korean).

8. H. Guleryuz and H. Cimenoglu, J. Alloy. Comp., 472, 241 (2009).

9. H. L. Du, P. K. Datta, D. B. Lewis and J. S. Burnell-Gray, Corrosion Sci., 36(4), 631 (1994).

10. M. P. Brady, W. J. Brindley, J. L. Smialek and I. E. Locci, J. Met., 48(11), 46 (1996).

11. Y. Shida and H. Anada, Corrosion Sci., 35(5-8), 945 (1993).

12. R. W. Taylor, Am. Mineral., 49, 1016 (1964).

13. C. Leyens and M. Peters, Titanium and Titanium Alloys; Fundamentals and Applications, p.17, Wiley-VCH, German (2003).

14. U. T. Son, Corrosion of Metals Engineering, p. 265, Namyoungmunhwasa, Seoul, Korea (1981) (in Korean).

15. D. R. Gaskell, Physical Metallurgy, 4th ed., p. 447, ed. R. W. Cahn and P. Haasen, Elsevier Science, BV, USA (1996).

16. K. L. Luthra, Oxidation of Metals, 36(5-6), 475 (1991). 